\title{
The end of the Celtic Tiger: an Irish case study on the failure of corporate governance and company law
}

\author{
PROFESSOR IRENE LYNCH FANNON*
}

School of Law, University College Cork

\begin{abstract}
$\underline{\text { Abstract }}$
This article considers the effect, if any, that company law and corporate governance law ${ }^{1}$ had on the phenomenon of excessive lending and borrowing that occurred in the Irish economy towards the end of the Celtic Tiger era (1990-2008). The final years of the Celtic Tigerperiod saw the growth and collapse of the Irish property bubble, fuelled by lending of 'cheap' money by Irish banks and borrowing by indigenous Irish property development companies. This chain of events culminated in a state guarantee and bailout of the Irish banking sector which has led to ongoing significant damage to Ireland and its economy, the full consequences of which are continuing to be manifest. What is clear is that excessive risktaking by banks, as lenders, and property development companies, as borrowers, led to the collapse of both sectors. ${ }^{2}$ The Irish property bubble, and this pattern of behaviour that caused it, is used here as a case study to raise questions as to why corporate governance law and company law seem to have failed to curtail such risktaking during this period. In describing these events from a legal perspective, the paper hypothesises that the failure of law can be explained by considering the inter-relationship between law and non-legal norms, the latter seeming to be more powerful and to have the ability to trump the rule of law in certain circumstances and contexts. This analysis of the role of non-legal norms is not intended to suggest that legal frameworks do not matter, but more to illustrate that, where they have failed to deliver stated goals, other factors must be understood so that the law can address the causes and drivers of this failure.
\end{abstract}

* I would like to acknowledge the support of the Irish Research Council and the Dean of Law's strategic fund at University College Cork for this research project. The research assistance of Lorcan Hurley LLM is also acknowledged. Versions of this paper have been delivered at: the Irish Association of Law Teachers Conference in November 2013; at the Corporate Law Teachers Conference of Australia, February 2014; and as a lecture at the Commercial Law Centre at the Law School at the Australian National University, Canberra, February 2014. Parts were also delivered at an Identities Conference at University College Cork in May 2012. I am grateful to all those who took the time to comment on this work.

1 Marc T Moore, Corporate Governance in the Shadow of the State (Hart 2013) 3, 62-65, 65ff, refers to a distinction between the two areas of corporate governance and company law. In this author's view, corporate governance and company law are intertwined with perhaps the latter being a subset of the former. The breadth of scholarship in the corporate governance arena, emanating from political theorists, economists and lawyers, contains within it a disagreement as to its parameters. Authors such as Moore favour a narrow conception of corporate governance, others favour a broader definition. Company law sits within this broader framework.

2 Whilst in hindsight the level of risk was clearly excessive, as described in various reports to date (see $\mathrm{n} 3$ below) and adumbrated by the current Banking Inquiry being conducted by the Oireachtas (see $<$ www.oireachtas.ie/inquiries/banking $>$ ), this article does not seek to pre-empt or predict any questions regarding culpability in this regard. See generally I Lynch Fannon and G N Murphy for a discussion of such standards in Corporate Insolvency and Rescue (Bloomsbury Professional 2012) chs 10 and 11. The US litigation involving Citigroup is also interesting on this question: Re Citigroup Inc Shareholder Derivative Litigation 964 A 2d 106 (Del Ch 2009). 


\section{Introduction}

Three distinct questions generated by the Irish crisis are identified in this article. ${ }^{3}$ First, issues concerning failure of sectoral regulation, particularly regarding the financial services and banking sector are of interest. This particular aspect of the crisis seems to be a reflection of what went wrong generally in other economies. ${ }^{4}$ The focus of this article is on company law and corporate governance law only. It is not intended to explore the regulation of financial services in any great detail.

Nevertheless, the legal framework generally is driven by a particular set of assumptions made at a level of political or legal theory and this article seeks to describe and locate Ireland within such a framework. In doing so, it hopes to highlight issues concerning ineffective use of legal rules, particularly in the corporate law field. ${ }^{5}$

Second, the internal governance of both the privately held property-development company (as borrower) and the multinational stock exchange-listed Irish bank (as lender) is of interest. Corporate governance is concerned with accountability which can be delivered through internal governance mechanisms determined by a corporate law framework, coupled with voluntary codes of self-regulation and, in some cases, through externally driven public law enforcement of management obligations. None represented a significant force in preventing the crisis. The question is why not?

Finally, this article proposes that some key aspects of failure of legal constraint can only be understood with reference to 'non-legal norm' scholarship. ${ }^{6}$ In considering the failure of law in this broader context, this article considers the Irish crisis and the failure of corporate law and corporate governance law through the prism of non-legal norm scholarship, which is of continuing interest to this author.

Part 1 of the article briefly describes the development of the Irish economy from 1990 to 2006 and the growth of the Celtic Tiger. It also describes the growth of a significant property bubble in Ireland from around 2002, fuelled by lending from Irish banks to indigenous property-development companies, to its ultimate collapse in 2008, the latter triggered by a global financial crisis. This bursting of the property bubble led to catastrophic effects in the Irish banking sector which, in turn, were addressed by a state bank guarantee

3 The Irish Banking Crisis: Regulatory and Financial Stability Policy 2003-2008 (Honohan report) (May 2010); Klaus Regling and Max Watson, A Preliminary Report on the Sources of Ireland's Banking Crisis (May 2010); Peter Nyberg, Misjudging Risk: Causes of the Systemic Banking Crisis in Ireland, report of the Commission of Investigation into the Banking Sector in Ireland (Nyberg report) (March 2011).

4 John C Coffee, 'What Went Wrong? A Tragedy in Three Acts' (2009) 6 University of St Thomas Law Journal 403. See also John C Coffee, 'What Went Wrong? An Initial Enquiry into the Causes of the 2008 Financial Crisis' (2009) Journal of Corporate Law Studies 1. For a description of the regulatory context in which financial services and the banking sector operated in Ireland, see generally Mary Donnelly, The Law of Credit and Security (Thomson Reuters Professional 2011), in particular chs 1 and 2, which refer extensively to the various government and official reports on this matter.

5 For further consideration of the Irish crisis in the context of financial regulation and the regulation of financial service institutions generally, see Blanaid Clarke and Niamh Hardiman, 'Hubris and Nemesis in Ireland' in Sue Konzelmann and M Fovargue-Davies (eds), Banking Systems in the Crisis: The Faces of Liberal Capitalism (Routledge 2012).

6 See generally Norms and Corporate Law Symposium (2001) 149 University of Pennsylvania Law Review 1. 
and bailout. ${ }^{7}$ Part 2 will describe how Ireland placed itself both legally and politically as a small open economy during the years of spectacular economic growth and how the consequent development of a particular regulatory approach contributed to the crisis. Many commentators have considered the failure of regulatory action in relation to banking and financial matters. ${ }^{8}$ The manner in which legal frameworks are developed, but also enforced, is reflective of a political context and it is interesting to see how theoretical debates affected the development of a legal and regulatory approach in Ireland. Part 3 will focus on company law and corporate governance law and what seems to be a failure of an apparently sophisticated legislative framework to address, or indeed prevent, an event of such cataclysmic proportions. Because of the similarity of Irish company law to company laws of other common law countries, this part will present Ireland as a case study to explore questions which, it is hoped, are relevant to company lawyers from many jurisdictions about the proper functioning of company law in the face of powerful forces which can be described from a norm scholarship perspective. Part 4 will raise some questions about the inter-relationship between law and non-legal norms. The central question is, therefore, about the effectiveness of corporate governance scholarship in the decades preceding the financial crisis, particularly that scholarship emanating from a law and economics disciplinary background. It would seem that, regardless of the expertise of those writing in this field, corporate governance failed its biggest challenge. Similarly, the effectiveness of company law is also a matter for concern. The final part attempts some simple propositions as a conclusion.

\section{From growth to bubble 1990-2006}

In considering the development of the Irish economy from 1990 during the following two decades, a distinction can be made between the first part of this account, which describes the birth and growth of the Celtic Tiger economy, and the second part, which describes the development of the property bubble and the ultimate collapse of the economy in 2008 . This provides an important context to my claim regarding norms and the law's failure to prevent excessive risktaking.

\section{ACt ONE: IRELAND's ECONOMIC BOOM AND GROWTH: the 'TRUE CELTIC TIGER' YeARS?}

Ireland's overall economic success in the period from 1996-2004, or possibly 2006, was certainly historically significant. The average growth rate in gross domestic product (GDP) in Ireland between 1996 to 2000 was about 9 per cent year on year, with the year 2000 showing a decline in the figures but still showing an average growth figure of around 4 per cent from 2000 to 2005.

Significantly, Ireland demonstrated exceedingly low unemployment figures in comparative European terms during this period. Before this time, during the 1980 s and

7 See further John Armour, 'Making Bank Resolution Credible' (2014) ECGI Working Paper Series in Law, Working Paper No 244/2014 (Oxford Handbook of Financial Regulation (OUP 2015 forthcoming)), where the author lists in note 6 the US 'crisis banks', which include Citigroup, AIG, Bank of America, Lehman Brothers, Bear Stearns, Merrill Lynch, Goldman Sachs, Morgan Stanley, Wachovia and Washington Mutual. Three solutions to these bank failures are described and the author refers to those which were allowed to fail, those which merged to avoid failure, or those which received special emergency assistance. In Europe the focus was on banks in particular states: Portugal, Italy, and most specifically Greece, Ireland and Spain $<$ http://papers.ssrn.com/sol3/papers.cfm?abstract_id=2393998> accessed 20 July 2014.

8 See nn 3, 4, 5 and 7 above for some examples.

9 Much of the underlying material to support this part of the paper is derived from an earlier work: I Lynch Fannon, 'The Luck of the Irish or Just Plain Old Tax and Regulatory Planning?'(2006) 1 Entrepreneurial Law Journal 1 (Ohio State Law School). See also Lynch Fannon and Murphy (n 2) ch 1. 
early 1990s, Ireland's unemployment figures hovered around 18 per cent, with relatively severe regional variations. This figure fell to 4 per cent and continued to decline right up until the property/construction sector collapsed. ${ }^{10}$ In countries such as France, Italy and Germany, the unemployment figures were in double digits for all of the period under consideration. There was no doubt that economic growth during this period was remarkable. That said, some commentators have pointed to factors which have led to a less euphoric view of the growth figures.

- One factor that is generally accepted as having contributed to economic growth is the level of foreign direct investment (FDI) into Ireland. As a result, the figures for growth in GDP do not bear an exact correlation to gross national product (GNP) figures, which are usually closely aligned. In Ireland, because of the significant repatriation of foreign profits, the differential is estimated at between $20-25$ per cent. ${ }^{11}$

- More interestingly, the period of apparently spectacular economic growth was preceded by periods of stagnation which should not have occurred. For example, during the period 1977 to 1984 the government pursued fiscal and economic policies which are viewed as having had a damaging effect on overall economic performance. ${ }^{12}$ In addition, Ireland's relatively poor economic performance in the 1950s and particularly in the 1960s meant that some part of this growth involved catch-up with its European neighbours, although commentators are divided as to the significance of this catch-up point. Nevertheless, this point, made primarily by historian Joe Lee, allows us to begin to understand the collective euphoria with which Irish people enjoyed the boom period. Quite simply, we had never experienced anything like it before. This fact is relevant to the role of non-legal norms, which I discuss in part 4.

According to various reports issued by respected agencies, both domestic and international, in the middle of the decade $2000-2005,{ }^{13}$ the short-term trajectory for this economic growth was that it was expected to continue. However, by that time others were

10 Eurostat (figures from 10 August 2006) <http://ec.europa.eu/eurostat/statistics-explained/>.

11 'The presence of a substantial foreign owned industry sector generates a substantial repatriation abroad of profits and dividends, which must be deducted in the calculation of GNP. As a consequence, on average, Ireland's GDP measure exceeds GNP by a factor of between $20-25 \%$, which is a crude measure of the overstatement of income, or living standards for Ireland, that is inherent in use of the international standard GDP measure.': Enterprise Ireland, Ireland Economic Profile 2 (2005) <www.enterprise-ireland.com/en>. See further Organisation for Economic Co-operation and Development (OECD), OECD Economic Surveys: Ireland (2006) (hereinafter OECD 2006) 19-21, 41. See also A Bergin et al, 'The Irish Fiscal Crisis' (2011) 217 Economic and Social Research Institute(ESRI)/National Institute Economic Review R47-R59.

12 Brian Nolan et al, Bust to Boom? The Irish Experience of Growth and Inequality (Institute of Public Administration 2000); Kieran A Kennedy et al, The Economic Development of Ireland in The Twentieth Century (Routledge 1988) 87-90. Joseph Lee, Ireland: Politics and Society 1912-1985 (CUP 1989).

13 'The Quarterly National Accounts for the third quarter of 2005 show GNP to have increased by 7 per cent in volume terms since the same period in the previous year... We believe that this strong performance will persist for the remainder of 2005 and that it will continue into 2006. For 2005, we think GNP will have grown by 5.0 per cent and that GDP will have grown by 4.8 per cent. For 2006, we forecast growth in GNP of 4.8 per cent [sic] and 4.7 per cent [sic] for GDP.': Alan Barrett et al, Quarterly Economic Commentary, Winter 2005 (Economic and Social Research Institute January 2006) $1<$ www.esri.ie/pdf/QEC2005Win_ES.pdf>. See ESRI <www.esri.ie>; Enterprise Ireland (n 11) 3; Industrial Development Authority Ireland, Ireland Vital Statistics 4-5 (2006) <www.idaireland.com> (hereinafter IDA Ireland). See also OECD 2006 (n 11) 19-21. 
warning that sound economic and financial factors were being supplanted by a housing and property bubble. ${ }^{14}$

\section{ACT TWO: THE GROWTH OF THE PROPERTY BUBBLE - HOW THINGS STARTED TO GO WRONG ${ }^{15}$}

Following the period of real and significant economic growth from the late 1990s, the train started to accelerate in a way which ultimately became unmanageable. The flow of cheap capital and the pattern of lending by Irish banks developed in extraordinary ways. The willingness of property-development companies to borrow significant sums to fuel land acquisitions and property projects turned out to be breathtaking in terms of a lack of risk aversion or ordinary risk analysis. During this time, as the Honohan report states, 'real residential property prices jumped to almost four times their historic norm'. ${ }^{16}$ 'Taxation policies continued to support property acquisition and speculative land transactions and, accordingly, the tax base also changed. Again as Honohan states, the tax take shifted away from traditionally reliable sources of income tax and, instead, significant gains were made in capital gains tax and stamp duties, all driven by an out-of-control property market. Accordingly, the government of the day had an immediate incentive to continue supporting the property bubble as tax revenues related to property transactions continued to grow and public spending continued to increase, affecting public sector salaries and the provision of public services in a positive manner.

A significant feature of this property bubble was that activity in the construction sector became over-focused on residential property construction and, in fact, the commercial sector did not mirror the enormous levels of activity in the residential sector at any point, perhaps an early indicator that the fundamentals were skewed. ${ }^{17}$

Finally, when the global financial crisis occurred, the Irish banks found themselves in considerable difficulties. In 2008, the government agreed to provide a blanket guarantee to the Irish banking sector, thus converting private debt into a sovereign debt problem of horrific proportions, leading to a significant impact on public sector finances. This had immediate consequences regarding public sector salaries and, more seriously, regarding the provision of public services in Ireland, including the public health sector, the education sector and the provision of social welfare services, with ongoing difficulties and hardship being experienced by all sectors of Irish society.

When considered in the overall European context, the figures from 2005 to those most recently available illustrate that Ireland has experienced what could only be described as a 'roller-coaster' ride in terms of GDP growth and subsequent decline, compared even with its closest European neighbours. Thus, in 2005 Ireland's GDP growth rate averaged 5 per cent for that year but in 2009, within a period of four years, the GDP rate of decline averaged -9 per cent. ${ }^{18}$ National debt increased from 20 per cent of GDP in 2007 to 84 per cent of GDP in $2012 .{ }^{19}$ Household indebtedness, as a percentage of gross disposable

14 'IMF Warns That House Prices May Have Risen Too High' Irish Times (Dublin 8 August 2003); 'Property in Ireland Overvalued' Economist (London 16 June 2005); OECD, Recent House Price Developments: The Role of Fundamentals (OECD, 2005). See also Bergin et al (n 11).

15 Honohan report (n 3).

16 Ibid 24.

17 See further Lynch Fannon and Murphy (n 2) ch 1 for additional material.

18 In the Euro 15 Zone, the figures for the same years are just under 2\% growth rate in 2005 and $-4 \%$ decline in 2009, showing a much less significant 'swing' than that of Ireland. In 2010 the Euro Zone 15 showed a small overall growth rate, whereas the figures were still negative for Ireland for 2010.

19 ESRI, Report on Government Debt 2000-2012 (Autumn 2013). 
income, also began to grow remarkably from 2002 and has continued to grow every year since then. ${ }^{20}$

\section{CONCLUSION}

In conclusion of this part, all of the factors which contributed to the initial period of growth persisted through the economic crisis and it would seem that the positive factors described in the first period of growth leading to what is called the 'true Celtic Tiger' period $^{21}$ are now contributing to Ireland's recovery. ${ }^{22}$ Nevertheless, Ireland is still saddled with significant sovereign debt because of the events surrounding the bank guarantee and bailout, with significant social consequences. Accordingly, questions as to how and why this banking collapse occurred are really important. The level of growth and decline is briefly described so that we can better understand the extent to which particular policy approaches failed to respond to increasingly unwarranted risktaking. An important part of this analysis relates to the apparent irrelevance of both corporate governance scholarship and rules and company law to prevent or rectify these problems occurring within different types of companies.

At this point, the scope of this paper ought to be clarified. Although the roles of the regulators, the Financial Regulator, the Central Bank and the Department of Finance, are mentioned in passing because they are referred to in the official reports and analysis of the Irish crisis, the focus is exclusively on the question of the apparent irrelevancy of corporate governance principles and company law.

\section{Regulation and theory}

The immediate aftermath of the banking crash and the sovereign debt crisis was cataclysmic in its effect on Irish society. Unemployment increased to 14.7 per cent in $2012^{23}$ and emigration returned as a particularly Irish solution to economic difficulties. Household indebtedness is still a significant problem. Unlike the public protests in Greece, the Irish reaction was different, characterised by a stoic acceptance of austerity measures in the hope that things might improve rapidly. ${ }^{24}$ This article seeks to describe and explain the failure of law to address excessive risktaking effectively. Non-legal norms provide a way of understanding why our legal structures may have failed and so the following discussion of how regulation, law and its enforcement are shaped by political theory and discourse is an aspect of non-legal norm-based analysis which will be considered further in parts 3 and 4 .

20 Peter Bacon, 'The Macro Economic Context to NAMA and the Irish Property Market' (A\&L Goodbody Corporate Restructuring Summit, 29 September 2010); N Russell, B Maitre and N Donnelly, Financial Exclusion and Over Indebtedness in Irish Households (Department of Community, Equality and Gaeltacht Affairs/ESRI 2011). The government has introduced new legislation to deal with a personal insolvency problem, the Personal Insolvency Act 2012. Recently, the personal indebtedness problem is becoming more acute as banks progress to repossessing private homes: 'Banks Attempt to Repossess 7,000 homes' Irish Times (Dublin, 9 March 2015).

21 Honohan report (n 3) 21. See further Donnelly (n 4) 15-25.

22 See part 4 below. 'Data Reveals Strongest Growth Since Early 2000s' Irish Times (Dublin, 19 September 2014), reporting that GDP grew by $5.7 \%$ in Q1 and Q2/2014. However, as described above, the difference in Ireland between GDP and GNP is significant because of the reporting of multinational profits.

23 ESRI (n 19).

24 In November and early December 2014, protests regarding water charges had become a touchstone for general exhaustion with and resistance to austerity measures. See further Blanaid Clarke and Niamh Hardiman, 'Crisis in the Irish Banking System', UCD Working Papers in Law, Criminology and Socio-Legal Studies, Research Paper No 02/2012 now published in Konzelman and Fovargue-Davies (n 5). In this paper the authors examine the particularly Irish nature of the crisis as described in the official reports to which this paper also refers. See further part 4 below. 
In a very significant speech delivered in New York in May 2012, Irish President Michael D Higgins reiterated a fundamental theme of his presidency, namely the need to refashion a new sense of Irish identity as Ireland faced the economic crisis into which it had been plunged at that time. He mentioned the concept of ethics and the ethical life a number of times in this speech and referred to the need to re-imagine a citizenry of ethical economic actors in contrast to the immediately preceding years which were dominated by greed:

I want to, however, invoke this evening the act of remembering, not just as an act of retrieval but as a forward-looking act, as an exercise of will and of conscious choice, an essential part of the process of renewal, a recovery of such words of ethical life as might reveal an illumination of the unrealised possibilities of a future Irishness - na féidireachtaí gan teaorainn.

Such a creative impulse as we need now, not only for economic recovery, but for humanity, is one that will relocate economics for example, in a moral ethical context that is scholarly, reflexive and genuinely emancipatory, an economics within a culture. ${ }^{25}$

With this instruction in mind, some aspects of Irish political discourse as it manifested itself during the Celtic Tiger years will be considered, in particular, in the spheres of corporate and economic activity. This discourse influenced the regulatory framework in which the decline of the Celtic Tiger took place.

\section{UNDERSTANDING CAPITALISM}

The starting point is a contrasting speech delivered by Mary Harney then TD, Minister for Enterprise and Tanaiste, regarding regulation of the Irish economy. In this speech, given in July 2000, Ms Harney ${ }^{26}$ maintained that Ireland was closer to Boston than Berlin in its approach to economic and regulatory matters. In considering what this might mean to corporate lawyers and corporate governance scholars, this paper draws on an earlier work, a monograph entitled Working within Two Kinds of Capitalism which seeks to describe and explain two different understandings of corporate function and action which pertain in US and EU understandings of economic activity and corporate governance. The emphasis in that particular work was on the comparative regulation of the employment relationship within European companies compared with the lack of regulation of the same relationship in the USA. This comparison resonates with the 'Boston or Berlin' rallying cry. ${ }^{27}$ Law and economics scholarship and its analysis of corporations begins with the 'firm theory' of Coase, moving on with Alchian and Demsetz and on to Easterbrook and Fischel. ${ }^{28}$ In the work of the latter theorists, reliance was placed on the integrity of markets as a means of organising human and corporate affairs leading to a contractarian and liberal view of the role of corporate law and corporate governance law. In particular, reliance on the capital markets as a way of constraining corporate management was of central interest to these scholars. ${ }^{29}$ In terms of corporate governance affairs, this contractarian paradigm was particularly dominant in US theoretical thinking throughout the 1990s and up until the

25 See www.president.ie/index.php?section=5\&speech=1105\&lang=eng. The president has since launched an Ethical Initiative, in April 2014.

26 See <www.djei.ie/press/2000/210700.htm>.

27 I Lynch Fannon, Working Within Two Kinds of Capitalism (Hart 2003).

28 F H Easterbrook and D R Fischel, The Economic Structure of Corporate Law (Harvard University Press 1991).

29 Eugene Fama, 'Agency Problems and the Theory of the Firm' (1998) 88 Journal of Political Economy 288; and 'Efficient Capital Markets' (1991) 46 Journal of Finance 1575. 
recent crash. ${ }^{30}$ It also attracted the interest of UK corporate lawyers in the immediate period preceding the enactment of the 2006 UK Companies Act. ${ }^{31}$

An alternative school of thought, described by Chancellor William $T$ Allen of the Delaware court, in his remarkable analysis of corporate governance scholarship, ${ }^{22}$ is the social model grounded 'in the dominant concepts of continental Europe and a yet earlier age'. Allen states that those holding this more communitarian view are 'more willing to regulate and define the legal institutions of property and contract in service of social values'. (The legal institutions of property will include corporations.) Regardless of whether this view, based on a communitarian legal philosophy, is more 'European' than others, although it is asserted here that it is, what is clear is that in the decades preceding the financial crisis from 1990 onwards the hegemonic, liberal contractarian view prevailed. We are still challenged in our presentation of an alternative theory of corporations. ${ }^{33}$

In Ireland during the Celtic Tiger years, the catchphrase adopted by the Tanaiste was often repeated, with questions constantly being asked as to whether Ireland and its citizens saw themselves as more rightly identifying with Boston rather than Berlin. Such statements, while acknowledging the underlying differences in economic and political theory, failed to articulate the significance of these distinctions in real outcomes. ${ }^{34}$ However, in espousing a heightened sense of capitalist reform, policymakers in Ireland neglected to engage deeply with the US model which, despite its overt reliance on a neoclassical, liberal regulatory model, and although often characterised as being more liberal than the European model, nevertheless presents a heavily regulated environment at federal, state and local level. The continued debate about corporate tax is a good example of this misunderstanding. ${ }^{35}$

In identifying the romanticising of the conflict between Boston and Berlin, my hypothesis is that Ireland positioned itself in a particular context which fed into both a regulatory response to financial services and in an attitude (non-legal norm) to law enforcement. Ireland and the Irish became the 'uber-capitalists' of the world, displaying a remarkable distaste for and distrust of regulation. Noam Chomsky has described the

30 See Henry Hansmann and Reinier Krakman, 'The End of History for Corporate Law' (2001) 89 Georgetown Law Journal 439, for a robust assertion of the dominance of the US model. For a more balanced view, see further John Armour, Henry Hansmann and Reinier Kraakman, 'The Essential Elements of Corporate Law' in Armour et al (eds), The Anatomy of Corporate Law: A Comparative and Functional Approach (1st edn OUP 2004/2nd edn OUP 2009). For disagreement, see Lawrence Mitchell, Progressive Corporate Law (Westview Press 1996); and Corporate Irresponsibility: America's Newest Export (Yale University Press 2001).

31 See Moore (n 1). For an early contrary view in the UK, see Jonathan Plender, Going off the Rails: Global Capital and the Crisis of Legitimacy (John Wiley \& Sons 2003) for a very readable consideration of the role of capital in governance structures.

32 William T Allen, 'Contracts and Communities' (1993) 50 Washington Lee and Law Review 1.

33 See David Millon and other progressive corporate law scholars writing in the USA in the early part of the millennium: David Millon, 'Communitarianism in Corporate Law: Foundations and Strategies' in Mitchell, Progressive Corporate Law (n 30); David Millon, 'Why is Corporate Management Obsessed with Quarterly Earnings and What Should Be Done about It?' (2002) 70 George Washington Law Review 890; Joseph W Singer, 'Jobs and Justice: Rethinking the Stakeholder Debate' (1993) 43 University of Toronto Law Journal 475; Stephen Bottomley, The Constitutional Corporation: Rethinking Corporate Governance (Ashgate 2007).

34 For example, Irish people generally welcome regulation of the employment relationship, consumer regulation and environmental protection all emanating from the EU, but there seems to be a lack of understanding of this positive effect of a European social model approach to corporate governance when it comes to other more liberal market approaches in relation to other aspects of corporate activity.

35 BBC News, 'European Tax Havens faces Obama Action' <http://news.bbc.co.uk/2/hi/business/ 8036914.stm> (6 May 2009). The average corporate tax rate in the USA is $39.5 \%$ compared with the Irish corporate tax rate which is $12.5 \%$. Simon Carswell, 'Obama Names Ireland in Attack on Tax Policies of US Firms' Irish Times (Dublin 25 July 2014). 
'American passion for de-regulation', 36 a passion that reached its zenith in the boom years of the $1990 \mathrm{~s} .{ }^{37}$ During that same period, Ireland became more American than the Americans. The Dublin Financial Services Centre, one of the drivers of the new Irish economy, thrived on an approach to regulation which its representative association described as 'responsive regulation' in efforts to attract overseas funds business.

Ireland espoused 'light touch and responsive regulation' in the area of finance, insurance and banking in particular and low levels of corporate tax which are unheard of in most developed industrial economies. Referring to both preceding reports on the Irish crisis, the Nyberg report states:

Both reports agree on the failure of both the FR (the Financial Regulator) and the CB (Central Bank) to foresee or prevent the financial crisis. The report by Regling \& Watson, besides highlighting the importance of international developments and fiscal policy, stresses the role and activities of the FR. It was unclear to the authors what the FR knew and when, and also why the supervisory response was not more forceful. The Honohan report addresses this aspect as well, emphasising the way in which the principles-based approach to regulation was implemented. It also notes and discusses the modest policy activity of the $\mathrm{CB}$ despite its responsibility to promote the overall stability of the Irish financial system. ${ }^{38}$

However, whilst Ireland might have become the location of a particularly uber-capitalist type of regulatory framework, this resistance to regulation was not just an Irish phenomenon. In a political theory context, Sandel ${ }^{39}$ describes the decades immediately preceding the 2008 crash as the era of market triumphalism. ${ }^{40} \mathrm{He}$ describes how as a result, without 'quite realising it, without even deciding to do so, we drifted from having a market economy to being a market society'. He continues:

The great missing debate in contemporary politics is about the role and reach of markets. Do we want a market economy or a market society. What role should markets play in public life and personal relations? ${ }^{41}$

36 Chomsky refers to David Sanger, political analyst with the New York Times, as having identified this phenomenon. See Noam Chomsky, Profit over People: Neoliberalism and the New Global Order (Seven Stories Press 1999) 64.

37 The passing of the Sarbanes-Oxley Act was generally viewed as heralding the beginning of serious federal regulation of US corporations. Further federalisation has been resisted in the USA. See Stephen Bainbridge, 'Incorporating State Law Fiduciary Duties into the Federal Insider Trading Prohibition' (1995) 52 Washington and Lee Law Review 1189, reprinted in (1996) 38 Corporate Practice Commentator 1; “The Creeping Federalization of Corporate Law" Regulation 26: Sarbanes-Oxley: Legislating in Haste, Repenting in Leisure' (2006) 2 Corporate Governance Law Review 69; 'Director v Shareholder Primacy in the Convergence Debate' (2002) 16 Transnational Lawyer 45-62. The phrase 'quack corporate governance' was used to criticise further federal regulation of corporate governance: Roberta Romano, 'The Sarbanes-Oxley Act and the Making of Quack Corporate Governance’ (2005) 114 Yale Law Journal 1521, 1523. For a similar approach to European Commission regulation, see Luca Enriques and Dirk Zetzsche, 'Quack Corporate Governance, Round III? Bank Board Regulation under the New European Capital Requirement Directive’ (2014) ECGI Working Paper Series 249/2014, now published in (2015) 16 Theoretical Inquiries in Law 211. The Capital Requirement Directive and Regulation are discussed below in relation to independent directors.

38 Nyberg report (n 3) para 1.2.4.

39 Mark Sandel, What Money Can't Buy: The Moral Limits of Markets (Penguin 2012).

40 Ibid 18.

41 Ibid 15. 
During this same period, approaches to corporate governance and corporate law theory became similarly politicised and polarised. ${ }^{42}$ In the USA, where such debates are particularly robust, some argued for the dominance of the Anglo-American corporate governance model, which in the views of these writers was characterised by a shareholder-oriented approach, where corporate function was to maximise shareholder wealth, free from intervention from regulatory agencies, in particular, federal regulation. ${ }^{43}$ Legal academics in the USA and in the UK were particularly influenced by this approach and, in turn, wielded significant influence in the development of the corporate law framework. In the USA this ranged from resistance to federal regulation of securities law and other financial instruments as represented in the Sarbanes-Oxley Act ${ }^{44}$ to resistance in the UK to further Europeanisation of the corporate law landscape. ${ }^{45}$ Others, a minority, argued for an alternative view of corporate governance. Now some corporate governance scholars are beginning to see how this theoretical paradigm has become particularly problematic. ${ }^{46}$

In practical terms, this approach to regulation is certainly regarded now as a contributing factor to the failure to regulate the financial sector. In a series of reports on the international financial crisis and its causes, the failure to regulate or even to identify, through adequate supervision, certain aspects of risk management is a theme which is continually pursued, along with additional and possibly more significant macro-economic issues, such as flow of cheap capital into Europe. ${ }^{47}$ In Ireland, regulatory failure of the banking system seems to have been particularly significant. In their report on Ireland's banking crisis, Regling and Watson state as follows:

First, all of the ... problems of policy analysis ... and implementation were present in the Irish case. Second, policy problems in certain areas were unusually severe in Ireland; here, the weakness in tax policy . . . [which continued to support property market expansion] . . . and in the implementation of financial supervision must be cited. Third, Ireland was one of those cases where there were at least some instances of extremely serious breaches of corporate

42 See the discussion recently from two leading US academics decrying the politicisation of their earlier work: Ronald Gilson and Reinier Kraakman (2014) 'Market Efficiency after the Financial Crisis: It's Still a Matter of Information Costs', Stanford Law School Working Paper Series no 458 and Columbia Law School Center for Law and Economic Studies Working Paper Series no 470 at $<$ http://ssrn.com/abstract=2396608>, in which the authors complain about the politicisation of the efficient capital markets hypothesis.

43 Such writers included Henry Hansmann and Reinier Kraakman, see, for example, 'The End of History for Corporate Law' (n 30). See further Armour et al (n 3). Progressive corporate lawyers positing an alternative approach included Lawrence Mitchell (n 30) and Millon (n 33). These debates are described from a European perspective in Lynch Fannon (n 27); and I Lynch Fannon, 'Employees as Corporate Stakeholders: Theory and Reality in a Transatlantic Context' (2004) 27 Journal of Corporate Law Studies 155.

44 See n 37 above. See further Moore (n 1) for further description of this contractarian approach.

45 In Europe, harmonisation of European company law stalled on the need for compromise between a typically continental European approach to corporate law and corporate governance and the 'Anglo-American' approach. Compromise was so difficult to achieve that in many respects harmonisation of company law stalled during this period. See further the 2012 Action Plan for European Company Law and Corporate Governance discussed below.

46 Lynn Stout, The Shareholder Myth (Barrett-Koehler 2012); Colin Meyers, Firm Commitment (OUP 2013). See also ECGI Corporate Governance Debate, Dublin <www.ecgi.org> (May 2013). See further J Armour and J Gordon, 'Systemic Risk and Shareholder Value' (2014) Journal of Legal Analysis 35, arguing for office and director liability rules in 'systemically important financial firms' as a 'complement to (and substitute for) the prescriptive rules that have emerged from the crisis'.

47 European Commission, Report of the High Level Group on Financial Supervision in the EU (the de Laroisiere report) (Brussels 25 February 2009); UK Financial Services Authority, A Regulatory Response to the Global Banking Crisis (the Turner review) (Financial Services Authority March 2009); European Commission Committee on Capital Markets Regulation, The Global Financial Crisis: A Plan for Regulatory Reform (May 2009). See further Donnelly (n 4) chs 1 and 2. 
governance, going well beyond poor risk assessment, and eventually having a systemic impact. 48

In its Action Plan for European Company Law and Corporate Governance published in 2012, ${ }^{49}$ the European Commission observed: 'The financial crisis has revealed that significant weaknesses in corporate governance of financial institutions played a role in the crisis. 50 This plan has been followed more recently by a series of measures on revision of the shareholder rights directive, a recommendation regarding 'say on pay', i.e. executive remuneration, recommendations on 'comply or explain' principles in corporate governance, and a single member companies directive. ${ }^{51}$ All of these illustrate that weaknesses in both corporate governance and regulation of smaller companies were revealed during the crisis.

\section{CONCLUSION}

In conclusion to this part, there seems to be a general consensus amongst corporate governance scholars that corporate governance or more specifically 'bank governance failure' and indeed company law are not centrally to blame for the financial crisis. Factors such as 'lax monetary policy of the American Federal Reserve Bank, the policy and practice of credit financing the housing of broad masses of the population, the securitisation of credit ... the failure of rating agencies as well as of the regulators and supervisors' 52 were all really important external factors. Yet, when faced with these external factors, which presented significant challenges in terms of risk management, there seems to have been a considerable failure, despite the apparent sophistication of corporate governance and corporate law theory.

For company law and corporate governance scholarship, the danger is clear - it is is one of irrelevancy.

\section{The role of company law}

As the hypothesis is developed that the espousal of a contractarian, neoliberal paradigm pervaded banking and financial services regulation in Ireland, the truth is that, when we actually focus on the development of company law in the same period in Ireland, things take on a very different character. From 1990 to 2001, in particular, Irish company law continued to develop along lines which are very similar to the developments that took place in the UK and in other parts of the common law world during that time, although indeed the framework is less liberal than the UK. ${ }^{53}$ The Companies Acts of the 1990 s modernised Irish law and, significantly, a new piece of legislation - the Company Law Enforcement Act 2001 - increased the public law regulation of directors, shadow directors and other officers

48 Regling and Watson (n 3) 44. See also Honohan report (n 3).

49 Communication from the Commission to the European Parliament, the Council, the European Economic and Social Committee and the Committee of the Regions COM (2012) 740 final <http://eur-lex.europa.eu/legalcontent/EN/ALL/?uri=CELEX:52012DC0740.

50 Ibid 3.

51 European Commission Press Release, Brussels 9 April 2014. See also the Shareholder Rights Directive 2007/36/EC.

52 Klaus Hopt, 'Corporate Governance of Banks and Other Financial Institutions after the Financial Crisis' (2013) 23 Journal of Corporate Law Studies 219 and 238; Joseph A McCahery and Eric P Vermeulen, 'The Ignored Third Dimension of Corporate Governance' (2014) ECGI Working Paper Series, Working Paper no $255 / 2014$, in which the authors argue that particular corporate forms contributed to short-termism as expressed in the financial capital markets, which in turn exacerbated competitive lending. See also Conference on New Legal Thinking in Financial Regulation, Cambridge University, 29-30 November 2013.

53 Note that, in the UK, the development of certain provisions of the Enterprise Act 2002 and the Companies Act 2006 represent a shift to a more liberal market paradigm which never took place in Ireland in terms of legal development. 
of the company in relation to a whole range of directorial behaviours and misbehaviours. A new enforcement unit, the Office of the Director of Corporate Enforcement, ${ }^{54}$ was established. In addition, an increased awareness of the importance of company law and corporate law compliance resulted in significant regulatory outreach, not only from the new Office of the Director of Corporate Enforcement but also from the Companies Registration Office. This legislation also established a public body whose function was to keep Irish company law under review. ${ }^{55}$ In particular, the Director of Corporate Enforcement was given increased powers of supervision and enforcement, including director disqualification provisions, along the same lines as the UK Company Directors Disqualification Act 1986. 56

And so, we are left at this point with very challenging questions as to the relevance of company law principles to the decisions which were made within the relevant companies in the period leading up to the crisis.

\section{ECONOMIC CATASTROPHE: THE ROLE OF COMPANY LAW AND CORPORATE GOVERNANCE}

The dissonance between the sophisticated legal framework in which Irish companies operated, on a par with any other developed common law jurisdiction, and the outcomes, particularly leading up to the crisis in 2008 and its aftermath, is particularly marked. The framework in Ireland is similar to UK company law and, of course, is influenced by European regulation, as is the case with all member states of the EU.

There are two areas of company law that are particularly pertinent. First are rules which affect the internal relationship between shareholders and management, as the latter continued to take risks which affected the sustainable growth of the companies in question. This applies to both the borrowers and lenders. The question here is whether shareholders were aware of or concerned by excessive risktaking and, if not, why not? The question then is whether, if any shareholder wished to proactively prevent such risktaking, were there provisions which they could have used? Additionally, are there effective provisions which could retrospectively render management accountable for such risktaking? A second area of company law that is pertinent is the body of rules which seeks to constrain excessive risktaking by management; provisions relating to reckless trading or breaches of duties in terms of skill and care might be relevant here, in addition to issues surrounding conflicts which might have compromised the desired independence of directors or board members. ${ }^{57}$

The failure of company law to address aspects of the crisis which could have been addressed if company law and corporate governance rules were fully utilised is fascinating. Up until the 1990s, the use of the corporate form in Ireland had been bedevilled by a failure of engagement with corporate regulation. Even as late as 1998, the McDowell report stated that 60 per cent of Irish registered companies were non-compliant with even basic requirements to return a register of shareholders, directors and a basic form of audited

54 See $<$ www.odce.ie $>$.

55 See <www.cro.ie> and see also the Company Law Review Group <www.clrg.ie>.

56 For a general discussion of the development of Irish company law between 1990 and 2013, see Lynch Fannon and Murphy (n 2) ch 1.

57 S Le Mire and G Gilligan, 'Independence and Independent Company Law Directors' (2013) Journal of Corporate Law Studies 443; M Gutierrez and M Saez, 'Deconstructing Independent Directors' (2013) 1 Journal of Corporate Law Studies 63. See further the discussion of the EU Capital Requirement Directive below under the heading 'Independent directors'; Joan Loughrey, Directors Duties and Shareholder Litigation in the Wake of the Finanical Crisis (Edward Elgar 2012). 
accounts. However, the reforms which have been described in the previous section were designed to address these faults and, for the most part, in the general scheme of things they worked. ${ }^{58}$ The property sector in Celtic Tiger Ireland seems to have been an exceptional case.

\section{THE SMALL 'CORNER SHOP': THE BORROWERS}

Many of the dominant Irish property-development companies were private companies, not listed on the stock exchange (Irish, English or New York) and often operated as subsidiaries of a holding company with unlimited status in sophisticated group structures. (The adoption of an unlimited company as a parent company or holding company of a group of companies is designed to reduce disclosure requirements in relation to the financial affairs of the group as a whole.) The possibilities of public regulation through the operation of stock market rules, characterised as a type of public law dimension, was therefore limited, as was the nature of information available to shareholders and others under disclosure rules.

Typical of this kind of company was the fact that one person, or one family, was identified with the company, for example, Liam Carroll and Zoe Developments, a group of companies with an unlimited parent company, Vantive Holdings, the demise of which is discussed below. This unlimited company had three shareholders, Liam Carroll and two others who had worked with him from the beginning. Another property developer, Paddy McKillen, operated through a company called Dellway Investments. McKillen was also the majority shareholder in this company. Bernard McNamara was another example of a property developer who dominated a group of companies, as was Sean Quinn of the Quinn Group, a corporate group which was originally involved in insurance but became exposed, not only to the property sector, but also to the banking sector as a shareholder in Anglo Irish Bank. This fact is unusual given the size and value of economic activity represented by these companies. On the other hand, these companies or corporate groups experienced rapid expansion and were not companies which had grown gradually over time or, as with many family companies, over generations. A common characteristic was that they were all dominated by one person, as reflected in public discussion on the individuals mentioned above. What seems to have been completely absent is the possibility of a shareholder or shareholding group exercising what in corporate governance terms is described as a 'countervailing power'. The same is true of the McInerney Homes Group, a more established Irish construction company which had been building residential properties since the 1970s. The liquidation of this company is also considered below.

\section{THE 'MULTINATIONAL CORPORATION': THE BANKS AS LENDERS}

On the other side of the negotiating table were the Irish banks, led in the first instance by Anglo Irish Bank, now the Irish Bank Resolution Corporation (IBRC) which is now in liquidation. Seeing the pace of lending taken by this bank, other more traditional Irish banks with significant retail banking engagement throughout Ireland and in other countries followed suit. These included two pillars of Irish banking, Allied Irish Banks plc (AIB) and Bank of Ireland.

As this paper is considering the internal governance of the banks and not the externally driven regulation of banking practices, it is important to mention that the two major banks - AIB and Bank of Ireland - were quoted on the Irish, English and New York stock exchanges. Throughout most of the period of the Celtic Tiger, very healthy share prices satisfied shareholders and left no real chance that any shareholder activism would have occured if concerns were to grow about the risks being taken. The faith which some

58 See generally Thomas B Courtney, Company Law (3rd edn Bloomsbury Professional 2011). See also Lynch Fannon and Murphy (n 2). 
corporate governance scholars have in capital markets as a governance tool must now be shaken when it has become so clear that the capital markets simply reflect a very narrow measure of corporate success. ${ }^{59}$

The Irish banks would also have had sophisticated internal governance models, with the creation of boards with independent directors and with the chief executive officer's and chair's roles divided. A separate Financial Regulator operated in this particular regulatory space and the public law enforcement role of the Office of the Director of Corporate Enforcement could also have come into play. Nevertheless, it would seem that spectacular failures of internal and external controls regarding monitoring of risks in banking and construction sectors all occurred, leading to the current Irish crisis. This section will now consider a number of important corporate governance devices which one would expect to operate in an ex ante fashion.

\section{CORPORATE GOVERNANCE: INDEPENDENT DIRECTORS 60}

In relation to the operation of the boards of the multinational banks, the role of independent directors provides food for thought because it affected the banking crisis generally. Independent directors were considered to be a cornerstone of developed corporate governance models in the years preceding the crisis. The Cadbury report ${ }^{61}$ emphasised the importance of the independent director. However, various scholars have questioned the importance of independent directors in light of what has happened:

While having independent directors seems a general trend, two cautionary remarks are necessary. First, the fact that independent directors are required is of relatively little relevance by itself; what is decisive are the criteria for independence and who determines whether a non-executive director should be considered independent. Second, the effectiveness of having independent directors has not yet been empirically established. ${ }^{62}$

Post-crisis, the Walker review in the $\mathrm{UK}^{63}$ made a number of recommendations on independent directors, adding to those already made in the Cadbury report. In particular, the Walker review noted that greater emphasis should be given to ensuring that the total composition of a board should represent the correct mix of financial industry capability and high-level experience in other businesses. In effect, it was acknowledged that the move towards identifying independent directors also meant there was a loss of industry capacity.

59 See Gilson and Kraakman (n 42). The fact that this kind of competitiveness was driven by share price is mentioned in the EU Commission documents referred to above. See also the Nyberg report (n 3). See also Blanaid Clarke, 'Where Was the "Market for Corporate Control" When We Needed It?' in W Sun (ed), Corporate Governance and the Global Financial Crisis: International Perspectives (CUP 2011).

60 For an excellent consideration of the role of directors in Irish company law, see Deirdre Ahern, Directors' Duties: Law and Practice (Roundhall 2009); 'Legislating for the Duty on Directors to Avoid Conflict of Interest and Secret Profits: The Devil in the Detail' (2011) 46 Irish Jurist 82; 'Guiding Principles for Directorial Conflicts of Interests: Re Allied Business and Financial Consultants Ltd: O'Donnell v Shanahan' (2011) 74 Modern Law Review 596-607.

61 Sir Adrian Cadbury, Report of the Committee on the Financial Aspects of Corporate Governance (Cadbury report 1992); for the Australian position, see S J Gray, 'Corporate Governance and Board Composition: Diversity and Independence of Australian Boards’ (2007) 15(2) Corporate Governance 194. Le Mire and Gilligan (n 57); Gutierrez and Saez (n 57), in which the authors argue that voluntary regulations on directorial independence are a substitute for state action in the legislative arena.

62 See Klaus Hopt, 'Comparative Corporate Governance: The State of the Art and International Regulation' (2011) 59 American Journal of Comparative Law 1/(2011) ECGI-Law Working Paper No 170/2011 $<$ http://ssrn.com/abstract=1713750>. See further K Hopt et al (eds), Corporate Governance (OUP 1998). This author contributed a survey on Ireland in preparation for this collection.

63 Sir D Walker, A Review of Corporate Governance in UK Banks and Other Financial Entities (Walker review 2009). 
The point made here is that, despite considerable attention given to corporate governance policies and principles in the two decades before the crisis and despite the identification of independent directors as being an effective element of corporate governance, the financial crisis belies the faith placed in this kind of director. Post-crisis reports such as Walker have tried to effect a rebalancing of the role of independent directors. Other commentators have sought to improve on independent directors as an effective corporate governance device by exploring future possibilities for such directors. ${ }^{64}$ The EU Commission has focused on independence of mind, reflected in the introduction of specific requirements on directors in the EU Capital Requirements Directive ${ }^{65}$ and the EU Capital Requirements Regulation, the latter now part of Irish law. ${ }^{66}$

Some scepticism about the effectiveness of principles or 'soft law' initiatives, such as independent directors, as substitutes for regulation is warranted. It is noteworthy that, despite various recommendations on criteria and restraints for independent directors in the USA, UK and Australia, there is no constraint on the holding of stock options in any of these corporate governance codes. ${ }^{67}$ It is argued here that, without a prohibition on directors holding stock options, independence will always be compromised.

\section{CORPORATE GOVERNANCE: SHAREHOLDERS AS A COUNTERVAILING POWER 68}

The shareholder as a 'countervailing power' in corporate governance terms is considered here in light of the dynamics which seem to have actually occurred both within the property-development companies and in the banks in relation to shareholders. Two examples of Irish property development companies illustrate the enormity of this problem. In 2008/2009 it became clear that Liam Carroll's group Zoe Developments (referred to above) was insolvent and it sought the protection of the High Court and the possibility of corporate rescue through the 'examinership' process provided for in the Companies Amendment Act 1990. Ultimately, the High Court refused an application for the examinership of the Zoe Group and the rescue of the corporate group, ${ }^{69}$ which encompassed seven companies controlled by the developer Liam Carroll through a holding company, Vantive Holdings. These companies owned a combined debt of $€ 1.3 \mathrm{bn}$.

Interestingly, the independent accountant's report was produced by KPMG and predicted a surplus of $€ 10 \mathrm{~m}$ over a three to five-year period, on the assumption of a recovery in the Irish property market. In refusing the application, Kelly J stated that '[the] degree of optimism on the part of the independent accountant borders, if it does not actually trespass, upon the fanciful'.

Kelly J went on to refuse the application to appoint an examiner observing:

I have the gravest reservations about the projections on which the independent accountant has relied in forming his opinion. They appear to me to be lacking in reality given the extraordinary collapse that has occurred and the lack of any indication of the revival of fortunes in the property market.

64 See Guiterrez and Saez (n 57).

65 Capital Requirement Directive IV (Directive 2013/36/EU Articles 76-91).

66 Capital Requirement Regulation 575/2013 Article 435, SI no 159/2014 European Union (Capital Requirements) (no 2) Regulations 2014. See Enriques and Zetzsche (n 37).

67 See the very useful survey conducted by Le Mire and Gilligan (n 57), table 2, 470.

68 See generally Paul Rose and Bernard Sharfman, 'Shareholder Activism as a Corrective Mechanism in Corporate Governance' (2014) Ohio State Public Law Working Paper no 225 $<$ http://papers.ssrn.com/sol3/papers.cfm?abstract_id=2324151>.

69 Re Vantive Holdings [2009] IEHC 384. See also Re Vantive Holdings [2009] IESC 68. 
A second feature of the fate of this corporate group was that Liam Carroll, the driving force behind Zoe Developments, was hospitalised during the proceedings. In corporate governance terms, it is extraordinary that in a company of significant financial standing one individual could still be so closely and personally identified with his company, which at that time owed more than $€ 1 \mathrm{bn} .{ }^{70}$

The difference between previous recessionary periods in Ireland and the current situation is that in the past the banks would always have stood as independent creditors outside the corporate structure. In contrast, in this particular recession, because of the significant exposure of the Irish banks to the property sector, the banks did not enjoy an 'arms-length' relationship with the debtors - in corporate governance terms there was no 'countervailing power'. As the boom years fell to ashes, it became clear that the banks and the banking system were hopelessly compromised. As Kelly J observed: ${ }^{71}$

It is sometimes said that when small or modest borrowers from banks encounter difficulties in repaying their loans, then such borrowers have a problem. For those with large borrowings, it is the banks who have a problem.

Only in the later period, when the Irish banks had effectively been brought under the control of the state, do we see Irish banks objecting to examinerships as creditors with securities to enforce at 'arms-length'. ${ }^{72}$ This occurred in the McInerney case, with all the banks originally objecting to the examinership and also objecting to the proposed rescue scheme on the grounds that they would be unfairly prejudiced. McInerney Homes Ltd had been a major player in the Irish construction sector even before the Celtic Tiger era and sought the appointment of an examiner in August 2010. The appointment was opposed by a number of banks, including two banks which had been taken into state ownership, namely Bank of Ireland and Anglo Irish bank, and a third banking party, KBC Bank. In total, the company owed the banks $€ 113 \mathrm{~m}$. Following the appointment of an examiner and the preparation of a scheme designed to facilitate the survival of the company, the High Court, in a series of hearings reflecting the complexity of the situation, declined to confirm a proposed rescue involving investment from a US property investor. On appeal the order was confirmed by the Supreme Court in July 2011. ${ }^{73}$

The complexity of the economic context cannot be underestimated. As O'Donnell J observed, delivering the majority judgment of the Supreme Court in Re McInerney Homes Ltd:

This case has resulted in the somewhat surreal scenario that over a three day period this Court was occupied by teams of lawyers, accountants and assorted experts engaged in a bitter battle to gain control of an Irish property development company, united only in the apparent belief that the development of property in Ireland over the next decade would be a lucrative business . . . It might be observed that the prediction of the future development of the property market in Ireland is something that defeated policy makers and experienced developers and lending institutions over the past decade and brought the latter

70 Re Vantive Holdings [2009] IEHC 384. See also Re Vantive Holdings [2009] IESC 68.

71 Ibid.

72 See further Report of the Commission of Investigation into the Banking Sector in Ireland, Misjudging Risk: Causes of the Systemic Banking Crisis in Ireland (March 2011) <www.bankinginquiry.gov.ie/Documents/ Misjuding $\% 20$ Risk $\% 20$ - $\% 20$ Causes $\% 20$ of $\% 20$ the $\% 20$ Systemic $\% 20$ Banking $\% 20$ Crisis $\% 20$ in $\% 20$ Ireland.pdf $>$.

73 There were four separate hearings in the High Court in this case: the first judgment in January 2011 refusing confirmation of a scheme, Re McInerney Homes Ltd [2011] IEHC 4; the second an intermediary hearing allowing for a reconsideration of the matter [2011] IEHC 25; the third, judgment dealing with the effects of NAMA [2011] IEHC 61; and the final decision confirming refusal to confirm the scheme [2011] IEHC 63. 
two groups to financial ruin, and the companies to their present difficult unhappy state.

In terms of considering the relationship between law and non-legal norms, the role of the judiciary in this part of the unfolding story is worth considering. The statements of Kelly J in Vantive Holdings and O'Donnell $\mathrm{J}$ sound a sober and independent note in the midst of 'irrational exuberance' (a phrase originally coined by Alan Greenspan) which characterised the last days of the Celtic Tiger and the hubris that followed in its wake.

\section{THE ROLE OF SHAREHOLDERS: CONCLUSION}

On the basis of information available to us from the judgments and reported facts about these private companies, there seems to have been a total failure of any internal rules of company law to control the borrowing of these companies. No ex ante countervailing power emerged from the shareholders in these companies. There is no evidence, through litigation or through references in the judgments described above, to the existence of disagreement within these companies. There have been no reported minority shareholder actions arising from a questioning of decisions or a sense of disagreement with risks taken. No private shareholder actions have been taken on behalf of these companies against directors who may have acted recklessly or possibly breached duties in relation to skill and care or abuse of power. In other words, the range of company law remedies has remained a dead letter. What many of the property companies had in common was the dominance of a major shareholder, often a paterfamilias type of character. The exercise of borrowing decisions seems to have been a lot less about corporate governance and a lot more about family or personal relationship dynamics. The lack of diversity within the internal governance framework and the lack of sophisticated corporate governance structures were extraordinary given the monetary values involved. As the reports have stated, there is in contrast ample evidence of 'groupthink' and herd mentality. ${ }^{74}$ This observation was reiterated by Mr Nyberg when he appeared at the Oireachtas Banking Inquiry in December 2014:

I classify this as groupthink, which is thinking as one's peers does so as not to stick one's head up too far. It would explain to some extent the fact that everybody was unprepared for the crisis when it came and that everybody was more or less willing to accept the occurrence of risky behaviour on the part of the banks and the public sector. It is fair to say that it is also possibly one of the reasons that what happened not only in Ireland but in several other countries in the world was not caught, criticised or challenged by international organisations, academics, the media or consultants. Everybody believed in the same thing and nobody saw that for which they were not looking.

But there is also evidence of a strong family-type dynamic. Again, this is supported by observations from Mr Nyberg at the Oireachtas Banking Inquiry:

As I already stated, a systemic crisis can arise only when a large number of riskmitigating functions in many institutions in society have become impaired. For instance, it would be wrong to assign blame primarily to lenders and ignore the fact that a bad loan also requires that a borrower would have made a bad risk assessment on the possibility to handle credit.

\section{CORPORATE GOVERNANCE: PUBLIC LAW ENFORCEMENT}

A further possibility lies in a fairly dynamic proactive public law enforcement of directorial behaviour, disclosure regulations, audit and accounting regulation. As described, the work of the Office of the Director of Corporate Enforcement is very significant in the landscape

74 Nyberg report (n 3) para 1.6. 
of Irish Company Law (see www.odce.ie and the Company Law Enforcement Act 2001). ${ }^{75}$ However, this is ex post facto in its effect and, given the scale of the risktaking and its consequences, is completely inadequate to address the fall-out, even in terms of resources.

Similarly, no regulatory remedies were taken against any of these directors in the initial years, although there have been a few such initiatives recently reported. ${ }^{76}$ In a more narrow company law framework, a key concept is that of recklessness with legal equivalents in UK law under wrongful trading provisions. A similar standard exists in Australian and New Zealand corporate law. ${ }^{77}$ Admittedly, such standards are difficult to prove and this is not to presuppose the outcome of any such initiatives. It would seem that concerns which have been expressed regarding systemic risk are not easily matched with these standards.

Regulation of the banking sector was equally catastrophic. Despite the fact that both AIB and Bank of Ireland are stock exchange companies, there have been no corporate law remedies employed against any of the management (with the exception of the impending prosecution of executives in Anglo Irish Bank, now IBRC). ${ }^{78}$ AIB and Bank of Ireland were sophisticated, stock exchange-quoted companies. This is not to suggest that particular individuals are accountable or ought to be accountable. The only point is that there has been no activity in relation to any of the remedies available in company law - either private or public remedies.

\section{Back to basics: non-legal norms and law}

In this section, there are a number of issues which feed into a consideration of how the law and legal rules interface with other non-legal norms and values. The nature of elites, the value of reputation and its preservation and other 'values' are important in how we understand the effectiveness of law.

\section{UNCONSTRAINED CAPITALISM}

In this paper a number of aspects of the Irish story have been identified. An espousal of capitalism in its crudest form; a lack of engagement with political discourse regarding corporate function and the role of the corporation in our society; a lack of understanding of the importance of regulating the market to achieve social ends; and a lack of sophistication in our relationship to corporate form and its regulation, in particular an apparent lack of appreciation of the downside of commercial risktaking: all created the perfect storm. To date none of the major players, management or otherwise, have been held accountable to shareholders who lost the value of shares, particularly those in banks. Nor have we seen any management accountability to creditors of property development companies, primarily banker creditors which have now been taken over by the state or by the National Assets Management Agency (NAMA). Where shareholders cannot or do not

75 See Irene Lynch Fannon, 'The Dynamic Entrepreneur or the Totally Incompetent Fool? The Role of Norms in Identifying Legitimate Risk Taking under Irish Company Law' in R Keane and A O’Neill (eds), Corporate Governance and Regulation (Roundhall Press 2010) for a discussion of the work of the Office of the Director of Corporate Enforcement in taking disqualification and restriction actions against directors.

76 Criminal prosecutions for alleged breaches of s 60 Companies Act 1963 which prohibits financial assistance in the acquisition of a company's own shares were conducted in 2014 in relation to executives of AIB, now in liquidation as the IBRC; James Dwyer, 'No Surprise if Ultimately the Supreme Court Rules on Narrow Breach of Law in Anglo' Irish Independent (Dublin 22 April 2014).

77 Helen Anderson, 'Directors' Liability for Fraudulent Successor Company Phoenix Activity: A Comparison of the UK and Australian Approaches' (2014) 14 Journal of Corporate Law Studies 139-73.

78 'Anglo Executives McAteer and Whelan Charged over Alleged Euro 8m Fraud' Irish Times (Dublin 11 August 2014). 
act to remedy such a loss, this must surely point to a lack of coherence in current corporate governance theories.

\section{FAMILY OR GROUP DYNAMICS VERSUS SHAREHOLDER ACTIVISM}

Instead of what should have theoretically happened, either a collapse in share value where the corporate entities were listed companies or significant shareholder disquiet in private companies, perhaps expressed in some evidence of shareholder litigation, we are faced with no action whatsoever. The point is not that one would wish to see such eventualities, but the fact that these events did not occur raises questions about the relevance of company law, corporate governance principles and underlying theories.

\section{THE IMPORTANCE OF PROPERTY AND HISTORY: 'TO REMEMBER EVERYTHING IS A KIND OF MADNESS'79}

A culturally driven non-legal norm about the nature of wealth seems to have led Ireland in particular to an obsession with land and property development during the boom period leading to the financial crisis. Readily available funds were invested in property and land rather than in any other kinds of business development. In an interview with one of the developers who formed part of this group, Paddy Kelly, Fintan O’Toole described Kelly's situation in $2010 .{ }^{80}$ He described how at the height of the boom Kelly was worth $€ 350 \mathrm{~m}$. Now he's $€ 350 \mathrm{~m}$ in debt. In this interview Kelly made the very telling observation, as he and O'Toole drove to Castletown House in Celbridge, County Kildare, that: 'It was time the Irish went through the front gate.' In the interview with O'Toole he thought it important to tell O'Toole that his great-grandfather and namesake was imprisoned for his role in the Land League's struggle against ascendancy landlords. This relationship to the land - to property as a tangible source of wealth as distinct from manufacturing, retail, innovation and creativity - is part of our history, but also part of our downfall as we became increasingly reliant on one economic sector.

\section{GROUPTHINK AND THE TRAGEDY OF HUBRIS}

What really makes Ireland attractive to corporate America is the kind of economy which we have created here. When Americans come here they find a country that believes in the incentive power of low taxation. They find a country that believes in essential regulation but not over-regulation. On looking further afield in Europe they also find that not every European country believes in all of these things. The figures speak for themselves. It is a remarkable fact that a country with just 1 per cent of Europe's population accounts for 27 per cent of US greenfield investment in Europe. Political and economic commentators sometimes pose a choice between what they see as the American way and the European way. They view the American way as being built on the rugged individualism of the original frontiersmen, an economic model that is heavily based on enterprise and incentive, on individual effort and with limited government intervention. They view the European way as being built on a strong concern for social harmony and social inclusion, with governments being prepared to intervene strongly through the tax and regulatory systems to achieve their desired outcomes ... We in Ireland have tended to steer a course between the two but I think it is fair to say that we have sailed closer to the American shore than the European one. Look at what we have done over the last ten years.

79 Brian Friel, Translations (Faber and Faber, 1995).

80 Fintan O'Toole 'The Rise and Fall of a Celtic Tiger Tycoon' Irish Times (Dublin 17 July 2010). 
We have cut taxes on capital. We have cut taxes on corporate profits. We have cut taxes on personal incomes. The result has been an explosion in economic activity and Ireland is now the fastest-growing country in the developed world. And did we have to pay some high price for pursuing this policy option? Did we have to dismantle the welfare state? Did we have to abandon the concept of social inclusion? The answer is no: we didn't. ${ }^{81}$

This extract from the same speech cited above by the Tanaiste of the day in 2000 sums up the view of Ireland and its success which continued to feed into the Irish political sphere for the coming years. In retrospect these comments are breathtaking. Non-legal norms trump any legal principles available to those who might otherwise have used them. Shareholders, directors, creditors and others were quite simply not in a position to adequately assess the nature of the risks being taken, nor to do anything about them, certainly not in a legal sense. And so groupthink prevailed and the possibilities of giving voice to a countervailing view, particularly through legal means, became impossible. In a section entitled 'Herding and groupthink' the Nyberg report makes the following observation that:

Groupthink occurs when people adapt to the beliefs and views of others without real intellectual conviction. A consensus forms without serious consideration of consequences or alternatives, often under overt or imaginary social pressure. Recent studies indicate that tendencies to groupthink may be both stronger and more common than previously thought... One consequence of groupthink may be herding, if the views in question relate to institutional policies, but this need not be the case. (para 1.6.5)

\section{AN INDEPENDENT ${ }^{82}$ JUDICIARY}

As described above, the commercial court judges delivered particularly significant opinions at crucial points at the beginning of the crash. An independent and rigorous judiciary is recognised as one of the cornerstones of democracy. In Ireland, it became fashionable for members of the elite to openly criticise the judiciary for a lack of independence, in particular, allegations were made that some members of the judiciary were compromised in terms of personal exposure to property matters. Issues have arisen regarding judicial compensation and one litigant even questioned the independence of a judge simply on the basis that the judge had a mortgage with a bank involved in litigation against the litigant. ${ }^{83}$ In particular, criticisms were made by particularly high-profile businesspeople in relation to deliberations of tribunals of enquiry. Although an independent judiciary is underpinned in Ireland by provisions of the Constitution, when we discuss the content of this principle we find that there is very little in terms of 'hard law' outlining what we mean by this kind of independence. For that reason, my theoretical framework considers the contours of judicial independence and the understanding of what this might mean when shaped by non-legal norms which pertain to the culture of the bench. If we are to continue the enquiry on how corporate governance and corporate law can interface more effectively with non-legal norms, the concept of independence might be a good place to start. We might indeed, as

81 See n 25 .

82 See further Le Mire and Gilligan (n 57) for a discussion of the concept of independence in both contexts.

83 This concerned a statement made by Brian and Mary Pat O'Donnell in litigation presided over by Charleton J in the High Court in Dublin where they had been declared bankrupt. This allegation of bias was made in court and described by the judge as 'frankly absurd'; Irish Times (Dublin 2 September 2013). 
has been suggested, look at this concept as it has applied to the judiciary and translate what we know about how this operates to board independence. ${ }^{84}$

\section{A EUROPEAN SOlution to a EUROPEAN EXPERIENCE}

Ireland's economic success was in part predicated on the openness of its economy - a factor which had changed considerably since the 1990s. The exposure of the banking sector to availability of funds from overseas was a consequence of this openness. In a small endnote, Hopt observes that 'the greed and short-sightedness of investors, including financial institutions, in particular the German State banks' also contributed. ${ }^{85}$ The Irish state's banking bailout benefited bondholders in the Irish banks who had provided cheap sources of funding. Therefore, it is obvious that a European-wide approach is part of the solution to the difficulties. In her discussion of the European Single Supervisory Mechanism, Ferran $^{86}$ traces the development of this 'first fundamental step towards a European banking union' where the supervision of all Euro area banks will sit with the European Central Bank (ECB). Unfortunately, Ferran concludes on a pessimistic note, stating that regulatory harmonisation must underpin a functioning single supervisory mechanism: 'The less comprehensive the legal and regulatory framework at EU level, the more the ECB will have to rely on national authorities' which could lead to 'significant gaps in monitoring'. ${ }^{87}$ A non-legal norm which will operate powerfully in this context relates to the sense of a collective European enterprise amongst Europeans generally. Ms Harney's speech referred to above reveals a rather negative sense of Europe in the Irish psyche.

\section{Conclusion}

J C Coffee observes in his conclusion on 'What Went Wrong?' that 'simple rules often work better than complex ones'. ${ }^{88}$ Similarly, the extraction of simple conclusions, while often more challenging, can be more instructive.

In the last two decades, many scholars have considered various aspects of corporate governance, which is quite simply about accountability and legitimacy for those who control and manage corporate wealth. The failures of corporate governance theory and consequent rules raise questions about relevancy and about the following governance mechanisms, which had become central to corporate governance theory, corporate law theory and resulting legal standards. First, the market for corporate control is clearly irrelevant to the private company and, insofar as it relates to quoted or listed companies, had already been under scrutiny since the Enron days illustrated its failings. Second, shareholder activism was markedly absent in either the smaller 'corner shop' property-development companies or the larger, more formally operated 'multinational banks'. As a governance device, shareholder activism is enjoying renewed interest post-crisis, but it is interesting to note that no efforts

84 See further Donald C Langevoort, 'The Human Nature of Corporate Boards: Law, Norms and the Unintended Consequences of Independence and Accountability' (2000) Georgetown University Law Center 241402/200 and Le Mire and Gilligan (n 57). The Capital Requirement Directive and Regulation (n 65) also tackle the concept of independence of directors, emphasising 'independence of mind' necessary to enable directors to 'constructively challenge and oversee the decisions of management. Members must act with honesty, integrity and independence.' Suzanne Le Mire has also made this connection between the concept of independence as it applies to the judiciary and corporate directors: Suzanne Le Mire and Gabrielle Appleby, 'Judicial Conduct: Crafting a System that Enhances Institutional Integrity' (2014) 38(1) Melbourne University Law Review 1.

85 Hopt (n 52).

86 E Ferran, 'The European Single Supervisory Mechanism' (2013) Journal of Corporate Law Studies 255.

87 Ferran (n 84) 285.

88 See Coffee, 'What Went Wrong' (n 4). 
were made at any time by shareholders to actually formally remove directors from boards a right which is present in both Irish and UK company law. Third, the value of independent directors must be doubted. Perhaps it is true that knowledge, expertise and experience in the sector are more important than independence. Even if we think that there are advantages to independence, a hanging question is whether law can create independence. Rules which prevent perverse incentives such as stock options are therefore important. Fourthly, the role of law in the face of powerful non-legal norms must be further examined. In this case, such norms include: reputational interests; other cultural values and norms (property ownership as wealth and status); and the interconnectedness of elites to political forces, regulators and lawmakers in terms of policy development, which requires further research. Finally, the crisis has illustrated difficulties with the European ideal which are seriously challenging. Even within the scope of this paper it is clear that further harmonisation of laws and, therefore, further integration must take place at all levels. The prospects of disintegration are even more challenging. Resistance to further harmonisation of laws at a European level and to any kinds of federalised enforcement arising from deeply held cultural or political positions (norms) in the European family is also a challenge. 